\title{
PELATIHAN PENGENALAN E-COMMERCE UNTUK PENINGKATAN KEGIATAN KARANG TARUNA RW.01 KELURAHAN PINANGSIA KECAMATAN TAMAN SARI JAKARTA BARAT
}

\author{
Fitri Latifah ${ }^{1}$, Melan Susanti ${ }^{2}$, Anggi Oktaviani $^{3}$, Herman Kuswanto ${ }^{4}$, Hendri ${ }^{5}$ \\ 1,2,3,4,5 Teknik Informatika, STMIK Nusa Mandiri \\ Jl. Jatiwaringin Raya No.02, Kecamatan Makasar Jakarta Timur \\ 1 fitri.latifah@nusamandiri.ac.id,2melan.susanti@nusamandiri.ac.id,3anggi.oktaviani@nusamandiri.ac.id, \\ 4herman.kuswanto@nusamandiri.ac.id,5hendri@nusamandiri.ac.id
}

\begin{abstract}
Capacity building for members of the youth organization RW.01, Pinangsia Subdistrict, Taman Sari Subdistrict, West Jakarta, is increasingly significant, which is marked by the increasing number of activities held in the youth organization. Lack of knowledge about online salesperson tricks is an obstacle for members of youth organizations to open an online shop using E-Commerce. Based on these problems, the lecturers at the Nusa Mandiri School of Informatics and Computer Management, especially the Informatics Engineering Study Program, intend to provide E-Commerce Introduction and Training activities in the RW.01 youth organization, Pinangsia Village, Taman Sari District, West Jakarta in order to carry out community service programs assist in the use of E-Commerce in entrepreneurship implementation activities as the next work program for youth organizations so that they can open an online shop business and can create jobs.
\end{abstract}

Keywords: E-Commerce; Online Shop, Youth Organization , Workshop

\begin{abstract}
Abstrak
Peningkatan Kemampuan bagi anggota karang taruna RW.01 Kelurahan Pinangsia Kecamatan Taman Sari Jakarta Barat semakin signifikan yang ditandai dengan semakin banyak kegiatan yang diadakan di lingkungan karang taruna tersebut. Kurangnya pengetahuan mengenai trik penjulana secara online menjadi hambatan bagi anggota karang taruna untuk membuka usaha toko online penggunaan $E$ Commerce. Berdasarkan permasalahan tersebut dosen Sekolah Tinggi Manajemen Informatika dan Komputer Nusa Mandiri Khususnya Prodi Teknik Informatika bermaksud ingin memberikan kegiatan Pengenalan dan Pelatihan E-Commerce di lingkungan karang taruna RW.01 Kelurahan Pinangsia Kecamatan Taman Sari Jakarta Barat dalam rangka menjalankan program pengabdian kepada masyarakat dengan harapan dapat membantu dalam penggunaan E-Commerce dalam kegiatan pelaksanaan kewirausahaan sebagai program kerja selanjutnya bagi karang taruna sehingga mereka dapat membuka usaha toko online dan dapat menciptakan lapangan pekerjaan.
\end{abstract}

Kata kunci: E-Commerce; Toko Online; Karang Taruna; Pelatihan

\section{PENDAHULUAN}

Komunitas Karang Taruna RW 01 Pinangsia Taman Sari Jakarta Barat memiliki potensi dalam mengembangkan usaha didalam organisasi tersebut agar bisa menjadi organisasi yang mandiri. Hal ini dibuktikan dengan mulai berkembangnya beberapa usaha dari komunitas Karang Taruna tersebut. Namun sangat disayangkan, komunitas tersebut masih belum terstruktur dalam berwirausaha. Peningkatan Kemampuan bagi anggota karang taruna RW.01 Kelurahan Pinangsia Kecamatan Taman Sari Jakarta Barat semakin signifikan yang ditandai dengan semakin banyak kegiatan yang diadakan di lingkungan karang taruna tersebut [1].
Kurangnya pengetahuan mengenai trik penjulan secara online menjadi hambatan bagi anggota karang taruna untuk membuka usaha toko online penggunaan E-Commerce [2]. Literasi digital dalam hal ini ditujukan untuk semua lapisan masyarakat dan semua kalangan. Pemahaman masyarakat akan arti pentingnya litersi digitasl di era sekarang ini sangat penting. Perlu adanya sosialisasi atau penyebaran informasi ke masyarakat tingkat desa atau kelurahan [3]. Masyarakat dengan literasi tinggi menunjukkan kemampuan masyarakat berkolaborasi, berpikir kritis, kreatif, komunikatif sehingga dapat memenangi persaingan global [4][5].

Solusi yang ditawarkan untuk mengatasi masalah dilapangan adalah dengan memberikan 
pelatihan e-commerse bagi Kelompok untuk mengenalkan dan memasarkan produk mereka [6]. E-Commerse adalah penjualan dan memasarkan produk melalui media internet atau media online yang lainnya. Dengan menggunakan media online kita kita bisa menghemat waktu dan tidak memerlukan modal besar untuk mempromosikan produk yang kita punya [7]. E-commerce merupakan satu set dinamis teknologi, aplikasi, dan proses bisnis yang menghubungkan perusahaan, konsumen, dan komunitas tertentu melalui transaksi elektronik dan perdagangan barang, dan informasi yang dilakukan secara elektronik. Sehingga e-commerce merupakan salah satu cara untuk berbelanja atau berdagang secara online yang memanfaatkan internet dimana terdapat website yang menyediakan get dan delivery [8][9].

Dalam masa pandemi Covid-19 ini [10], pemerintah menghentikan pembelajaran secara offline \& diganti sebagai pembelajaran jarak jauh yang dilakukan secara daring. Sistem pembelajaran jarak jauh ini adalah solusi yang sempurna pada masa pandemik seperti saat ini supaya aktivitas belajar mengajar permanen bisa terealisasi digunakan, baik \& menyelamatkan para siswa supaya selalu dirumah saja \& meminimalisasi terjadinya penularan virus corona [11].

Penerapan ini dimulai bulan Maret 2020.

Menteri Pendidikan \& Kebudayaan berupaya supaya mutu pendidikan di Indonesia pada penyelenggaraan sistem pembelajaran jarak jauh ini konsisten terjaga. Sehingga asal daya yang didapatkan tetap memenuhi kualitas yang baik. Pembelajaran jarak jauh yaitu pendidikan yang dilaksanakan siswa \& pengajar, pada hal ini memenfaatkan media teknologi menjadi wahana buat menunjang pembelajaran yang dilakukan secara daring. Pembelajaran jarak jauh atau diklaim menggunakan kata Pendidikan Jarak Jauh (PJJ), bukan ketika ini saja penerapannya [12].

Berdasarkan permasalahan tersebut dosen Sekolah Tinggi Manajemen Informatika dan Komputer Nusa Mandiri Khususnya Prodi Teknik Informatika bermaksud ingin memberikan kegiatan Pengenalan dan Pelatihan E-Commerce di lingkungan karang taruna RW.01 Kelurahan Pinangsia Kecamatan Taman Sari Jakarta Barat dalam rangka menjalankan program pengabdian kepada masyarakat dengan harapan dapat membantu dalam penggunaan E-Commerce dalam kegiatan pelaksanaan kewirausahaan sebagai program kerja selanjutnya bagi karang taruna sehingga mereka dapat membuka usaha toko online dan dapat menciptakan lapangan pekerjaan.

\section{METODE PENGABDIAN MASYARAKAT}

Karang taruna adalah lembaga swadaya masyarakat non-profit yang dikelola secara mandiri oleh masyakarat di tingkat RW, demikian pula dengan warga RW 01 kelurahan Pinangsia Kecamatan Taman Sari Jakarta Barat, mengadakan pembinaan kepada pemuda - pemuda di lingkungan RW.01 kelurahan Pinangsia Kecamatan Taman Sari Jakarta Barat sebagai bentuk kepedulian masyarakat dilingkungan RW.01 Keluarahan Pinangsia Kecamatan Taman Sari Jakarta Barat.

Karang Tarunan ini dibentuk pada tanggal 28 Oktober 2018 bertepatan dengan hari sumpah pemuda, sebagai ketua adalah Yunita Chandra, kegiatan awal dari karangtaruna ini hanya terbatas pada pembinaan kesenian. Seiring dengan berjalannya waktu kegiatan karang taruna RW.01 Kelurahan Pinangsia Kecamatan Taman Sari Jakarta Barat berkembang tidak saja terbatas hanya kegiatan kesenian saja kegiatan yang saat ini di selenggarakan adalah Posyandu Remaja, Bakti Sosial, Kerja Bakti dan seminar PLAN Internasional. Berdasarkan hasil survei dan wawancara dengan pengurus karang taruna di RW.01 Kelurahan Pinangsia Kecamatan Taman Sari pada awal bulan Februari 2020, ternyata mereka menginginkan ada nya kegiatan wirausaha dengan cara membuka toko online untuk dapat membuka usaha dan membuka lapangan perkejaaan bagi generasi muda.

Bentuk kegiatan pengabdian kepada masyarakat (Abdimas) yang ditujukan kepada anggota karang taruna RW.01 Kelurahan Pinangsia Kecamatan Taman Sari Jakarta Barat berupa pengenalan dan pelatihan e-commerce dalam penggunaan tansaksi online mencakup pengenalan e-commerce, penggunaan e-commerce dan bagaimana melakukan transaksi dengan $e$ commerce.

\section{HASIL DAN PEMBAHASAN}

Kegiatan pembuatan e-commerce bagi Karang Taruna RW 01 Pinangsia Jakarta Barat dilaksanakan pada tanggal 2 Mei 2020 melalui online workshop menggunakan aplikasi ZOOM Meeting selama dua sesi, yaitu sesi pertama dilakukan jam 10.00 hingga 12.00 WIB dilanjutkan sesi kedua pada jam 13.00 hingga 15.00 WIB. Pelatihan berjalan dengan lancar dihadiri oleh 10 peserta dari 15 undangan. Peserta pelatihan terlihat antusias dalam menerima materi yang diberikan. Walaupun dunia sedang dilanda pandemik Covid-19, tidak menyulutkan semangat 
para pemuda Karang Taruna untuk belajar dan mengembangkan diri. Hal ini terlihat dari awal hingga akhir acara, semua peserta mengikuti dengan baik dan tertib.

Materi tentang pengenalan e-commerce dan model bisnis terkini dilakukan pada sesi pertama. Pada sesi kedua peserta pelatihan mulai diarahkan untuk membuat business plan secara langkah demi langkah. Hasil kerja peserta pelatihan dikumpulkan kemudian diberi masukkan dan selanjutnya diperbaiki lagi. Selama proses membuat business plan dilakukan tanya jawab dan diskusi antara peserta pelatihan dan pengabdi untuk meningkatkan pemahaman peserta. Berdasarkan hasil kegiatan dapat diidentifikasi mengenai tingkat pemahaman peserta pelatihan adalah sebesar $80 \%$ peserta pelatihan memahami konsep e-commerce, model bisnis terkini dan cara membuat business plan. Sebanyak 8 business plan berhasil tersusun dengan rapi sesuai dengan jenis bisnis yang diinginkan.

Dari hasil tersebut peserta pelatihan dapat merealisasikan model bisnisnya sesuai dengan business plan yang telah dibuat. Dalam pelaksanaan kegiatan ini peserta mendapatkan:

1. Modul E-Commerce;

2. Sembako;

3. Kuota Internet

Terlihat pada gambar 1 ketika tutor dan peserta mengawali pelatihan pengenalan $e$-commerce ini

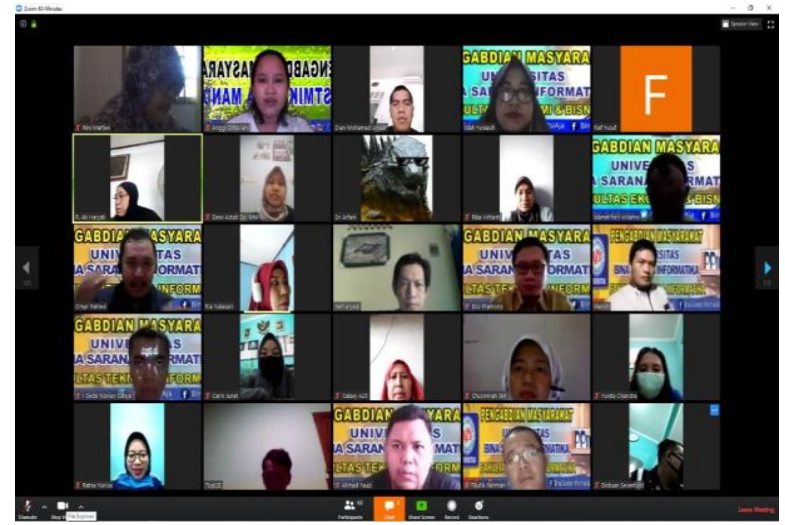

Gambar 1. Tutor menjelaskan tentang e-commerce

Dalam menjelaskan materi peserta langsung dikirim modul via Zoom Meeting sehingga peserta bisa membaca modul seklaigus mendengarkan arahan dari tutor. Seperti terlihat pada gambar 2 saat tutor menjelaskan lebih lanjut tentang $e$ commerce

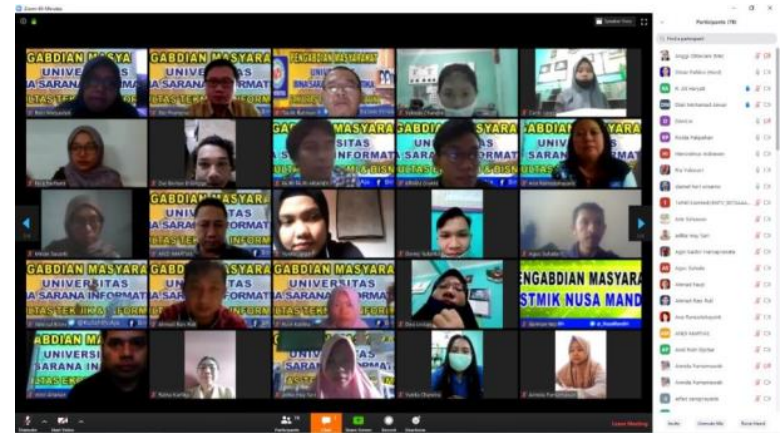

Gambar 2. Pembahasan materi lebih lanjut tentang e-commerce

Kemudian setelah acara selesai kami mengirimkan panitia yang sudah memenuhi standar protokoler kesehatan untuk membagikan bingkisan berupa sembako kepada peserta yang telah mengikuti kegiatan sampai akhir. Seperti terlihat pada gambar 3.

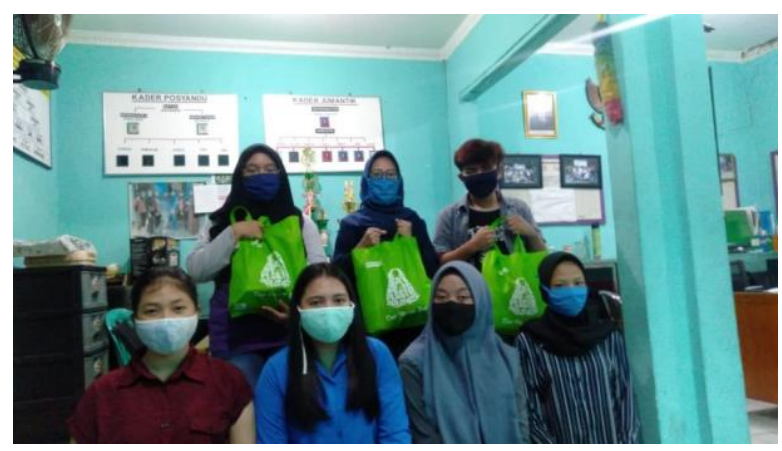

Gambar 3. Panitia membagikan sembako

Dalam pelaksanaan terkadang panitia dan peserta mengalami kendala namun juga selalu saja ada faktor pendukung yang membuat acara tetap bisa berjalan dengan baik. Adapun faktornya

1. Faktor Pendukung Kegiatan

Kegiatan pengabdian masyarakat yang dilaksanankan pada pemudaKarang Taruna RW 01 Pinangsia Taman Sari berjalan dengan sangat baik dan lancar. Para peserta pengabdian masyarakat sangat tertarik dengan materi yang disampaikan oleh tutor. Materi yang disampaikan mampu diserap dengan baik oleh para peserta pengabdian masyarakat. Dengan membahas materi tentang e-commerce, model bisnis terkini, membuat business plan hingga tips dan trik berwirausaha membuat para peserta senang dan antusias Beberapa faktor yang mendukung kegiatan ini adalah jaringan internet terhubung dengan baik sehingga proses ceramah dan diskusi tidak mengalami kendala yang berarti. Faktor selanjutnya yaitu antusiasme dari peserta pelatihan untuk memahami materi tentang $e$ commerce, pentingnya membuat business plan 
hingga kemauan untuk berwirausaha peserta pelatihan. Antusiasme dibuktikan dengan pertanyaan yang muncul saat sesi tanya jawab dan pengerjaan tugas membuat business plan.

2. Faktor Penghambat Kegiatan

Berlangsungnya kegiatan pengabdian masyarakat di masa pandemik Covid-19 merupakan salah satu faktor penghambat itu sendiri. Saat melakukan perencanaan awal, kelompok pengabdi telah kesulitan dalam menentukan metode yang tepat dalam melaksanakan kegiatan ini. Namun hal tersebut dapat diselesaikan dengan penggunaan media online sebagai sarana dalam proses pelatihan. Saat kegiatan berlangsung ditemukan pula kesulitan di sesi awal. Belum terbiasanya peserta pelatihan dalam melakukan pelatihan online. Hal ini terlihat dari beberapa kali peserta kesulitan dalam menggunakan beberapa fitur aplikasi pembelajaran online (Zoom Meeting). Namun hal tersebut hanya berlangsungdiawal saja, mengingat diperlukannya adaptasi dengan penggunaan halhal yang baru bagi peserta pelatihan. Faktor penghambat lainnya ialah tutor tidak terlalu leluasa dalam memberikan koreksi terkait hasil business plan yang telah dibuat oleh peserta. Hal tersebut disebabkan proses perbaikan membutuhkan lebih banyak waktu saat dilakukan secara online dibandingkan dengan offline dikarenakan ada proses kirim hasil tugas menggunakan email.

Setelah pelaksanaan kegiatan, peserta diberikan kuisioner sebagai bahan evaluasi dari kegiatan tersebut, pada sesi akhir pelatihan diberikan kuesioner sebagai tolok ukur kepuasan peserta dalam pelaksanaan pelatihan ini. Kuesioner dibuat dengan melampirkan 10 pertanyaan kepada 10 peserta pelatihan. Berikut rekapitulasi hasil kuesioner tersebut:

Tabel 1 Pertanyaan Kuisioner

\begin{tabular}{clcc}
\hline Kode & \multicolumn{1}{c}{ Pertanyaan } & Persentase \\
\hline P1 & $\begin{array}{l}\text { Personil/anggota yang terlibat dalam kegiatan pengabdian masyarakat memberikan pelayanan } \\
\text { sesuai dengan kebutuhan peserta }\end{array}$ & $84 \%$ \\
\hline P2 & $\begin{array}{l}\text { Tutor menyampaikan materi kegiatan dengan jelas dan mudah dimengerti oleh peserta } \\
\text { P3 }\end{array}$ & $\begin{array}{l}\text { Setiap keluhan/pertanyaan/permasalahan yang diajukan ditindaklanjuti dengan baik oleh tutor yang } \\
\text { terlibat }\end{array}$ & $86 \%$ \\
\hline P4 & $\begin{array}{l}\text { Materi yang disampaikan sesuai dengan kebutuhan peserta dalam menambah wawasan, } \\
\text { pengetahuan, keterampilan dan keahlian peserta }\end{array}$ & $78 \%$ \\
\hline P5 & Peserta mendapatkan materi kegiatan berupa modul dan soal latihan & $78 \%$ \\
\hline P6 & Peralatan untuk menyampaikan materi memadai & $98 \%$ \\
\hline P7 & $\begin{array}{l}\text { Kegiatan pengabdian masyarakat yang disampaikan bermanfaat untuk menambah wawasan, } \\
\text { pengetahuan, keterampilan dan keahlian peserta }\end{array}$ & $64 \%$ \\
\hline P8 & $\begin{array}{l}\text { Saya merasa puas dengan kegiatan pengabdian masyarakat yang diselenggarakan STMIK Nusa } \\
\text { Mandiri }\end{array}$ & $86 \%$ \\
\hline P9 & $\begin{array}{l}\text { Kegiatan pengabdian masyarakat yang diselenggarakan STMIK Nusa Mandiri sesuai dengan harapan } \\
\text { saya }\end{array}$ & $86 \%$ \\
\hline P10 & Jika kegiatan ini diselenggarakan kembali, saya bersedia untuk berpartisipasi/terlibat & $82 \%$ \\
\hline
\end{tabular}

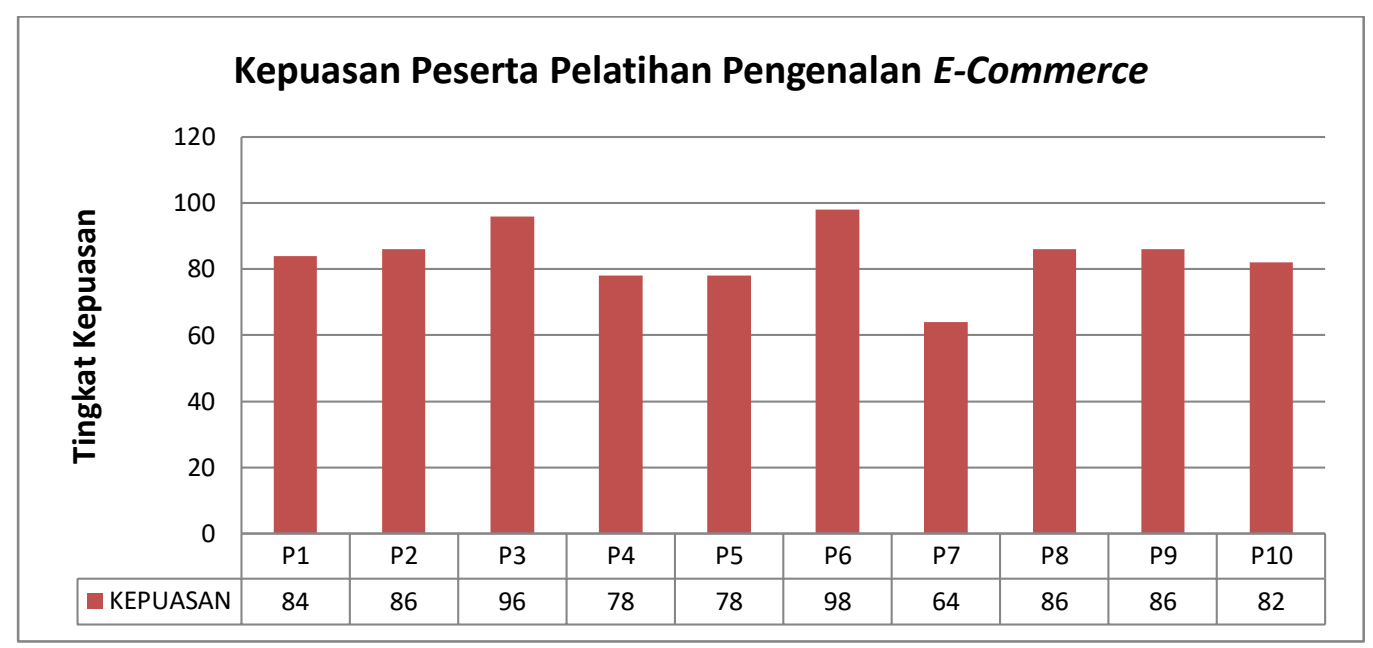

Gambar 4. Grafik Kepuasan Peserta 
Berdasarkan tabel 1 dan gambar 5 tersebut terlihat bahwa sebagian besar peserta pelatihan merasa puas dengan adanya pelatihan pengenalan e-commerce bagi Karang Taruna RW 01 Pinangsia. Dengan adanya hasil kuesioner tersebut menjadi bahan evaluasi bagi penyelenggara untuk menjadi lebih baik dalam menyelenggarakan pelatihan.

\section{KESIMPULAN}

Kegiatan pelatihan berjalan dengan lancar dan disambut dengan sangat antusias oleh para peserta. Peserta merasakan bahwa pelatihan yang diberikan sangatlah bermanfaat untuk menunjang tugas kerja mereka terutama dalam hal pembuatan e-commerce dan pengelolaannya. Pelaksanaan pengabdian untuk pemuda Karang Taruna RW 01 Pinangsia Jakarta Barat disimpulkan berhasil sampai tahap pelatihan dasar yaitu pengenalan ecommerce dan rencana bisnis. Keberhasilan ini ditunjukkan oleh (1) adanya kesesuaian materi dengan kebutuhan pemuda karang taruna RW 01 Pinangsia Jakarta Barat untuk mengembangkan organisasi Karang Taruna menjadi lebih mandiri; (2) adanya tanggapan yang positif dari peserta mengingat materi yang diberikan merupakan salah satu cara untuk bertahan dalam situasi dan kondisi pandemik Covid-19 yaitu dengan membuat business plan guna menciptakan e-commerce; (3) sebagian besar $(80 \%)$ peserta pelatihan mampu memahami dan membuat business plan dengan sistematis dan benar. Dari 10 peserta, terdapat 8 business plan yang berhasil tersusun dengan baik. Berdasarkan tanggapan dan pertanyaan peserta pelatihan, dalam membuat business plan disarankan agar peserta pelatihan dapat mengembangkan kreatifitasnya dalam membuat model bisnis yang dikehendaki terutama model bisnis yang terkini. Hal tersebut dikarenakan persaingan usaha semakin berat dan tantangan usaha semakin besar. Maka diperlukan pelaku usaha yang kreatif dalam memasarkan sebuah produk usaha. Untuk selanjutnyapemuda Karang Taruna meminta agar pelatihan serupa dapat dilaksanakan kembali dengan waktu yang lebih panjang dan peserta yang lebih banyak. Pengenalan dan pelatihan e-commerce bagi karang taruna RW.01 Kelurahan Pinangsia Kecamatan Taman Sari Jakarta Barat para peserta sangat antusias dan sangat bersemangat, dan mereka meminta untuk kesempatan PM yang akan datang dilanjutkan dengan pengenalan dan pelatihan pembuatan toko online sehingga mereka dapat mengaplikasikaan semua pengetahuan yang telah diberikan dalam membuka toko online. Dengan pengabdian masyarakat ini kami berbagi/ sharing ilmu pengetahuan yang ada di kampus kepada para masyarakat agar bermanfaat.

\section{UCAPAN TERIMAKASIH}

1. Pemuda Karang Taruna RW 01 Kelurahan Pinangsia Kecamatan Tamansari Jakarta Barat

2. Semua jajaran panitia dan tutor STMIK Nusa Mandiri

\section{DAFTAR REFERENSI}

[1] B. Givan, H. E. Indrawan, and A. O. Siagian, "Pelatihan Membuat Business Plan Bagi Pemuda Karang Taruna RW 01 Pinangsia Taman Sari Jakarta," J. Karya untuk Masy., vol. 1, no. 2, pp. 172-181, 2020.

[2] B. Setiawan, "Edukasi E-Commerce Pada Pelaku Usaha Mikro, Kecil Dan Menengah (Umkm) Di Kota Palembang," J. Abdimas Mandiri, vol. 2, no. 2, pp. 106-110, 2018.

[3] P. B. Widagdo, "Perkembangan Electronic Commerce (E-Commerce) di Indonesia," researchgate.net, pp. 1-10, Dec. 2016.

[4] I. N. A. S. Rai, S. Y. Putri, and W. R. D. Astuti, "IPTEKS Bagi Masyarakat: Pemberdayaan Ukm Melalui Kemitraan Dengan Pemerintah Kabupaten Serang Dalam Kegiatan Sosialisasi E-Commerce," J. ComunitÃ Serv. J. Terkait Kegiat. Pengabdi. Kpd. Masyarakat, terkhusus Bid. Teknol. Kewirausahaan dan Sos. Kemasyarakatan, vol. 1, no. 2, pp. 186-197, Nov. 2019.

[5] Dispusip Kota Pekanbaru, "Konsep Dasar Literasi,” dispusip.pekanbaru.go.id, 2019. [Online]. Available: https://dispusip.pekanbaru.go.id/konsepdasar-literasi/.

[6] B. A. Herlambang, K. Latifah, and N. Q. Nada, "PKM E-Commerce Bagi Kelompok Karangtaruna Dan Ibu-Ibu PKK Desa Tlogo Kecamatan Tuntang Kabupaten Semarang," JOIN J. Progr. Kemitraan dan Pengabdi. Kpd. Masy., vol. 1, no. 1, pp. 16-20, 2020.

[7] Carolina Ratri, Sukses Membangun Toko Online. yogyakarta, 2020.

[8] F. R. Lupi and N. Nurdin, "Analisis Strategi Pemasaran Dan Penjualan E-Commerce Pada Tokopedia.Com," J. Elektron. Sist. Inf. dan Komput. (JESIK, vol. 2, no. 1, pp. 20-29, 2016.

[9] Onno W. Purbo, Mengenal E-commerce. Jakarta: Elex Media Komputindo, 2001.

[10] F. Aziz, D. Riana, J. Dwi Mulyanto, D. Nurrahman, and M. Tabrani, "Usability Evaluation of the Website Services Using 
the WEBUSE Method (A Case Study: covid19.go.id)," J. Phys. Conf. Ser., p. 12103, 2020.

[11] D. E. Nugraheny, "Pemerintah Luncurkan Situs Resmi Penanganan Covid-19 untuk Masyarakat," Kompas.com, 2020. [Online]. Available:

https://nasional.kompas.com/read/2020/ 03/18/13095321/pemerintah-luncurkansitus-resmi-penanganan-covid-19-untukmasyarakat.

[12] S. Setiati and M. K. Azwar, "COVID-19 and Indonesia," Acta Med. Indones., vol. 52, no. 1, pp. 84-89, 2020. 